\title{
Vybrané aspekty studia v kurzech anglického jazyka na U3V ZČU v Plzni
}

\author{
Radmila Holubová, Jitka Ramadanová
}

\begin{abstract}
Abstrakt: Tento př́íspěvek je tematicky zaměřen na studium posluchačů Univerzity třetího věku (U3V) na Západočeské univerzitě v Plzni. Přestože otázka celoživotního vzdělávání seniorů vyvstává v posledních desetiletích v naší republice se stále větší naléhavostí, mimo jiné i vzhledem $\mathrm{k}$ demografickým trendům, v odborné literatuře není této problematice u nás věnována dostatečná pozornost. Autorky př́spěvku nejprve informují o studiu na U3V v Plzni obecně a následně se blíže zaměřují na kurzy anglického jazyka, které jsou seniorům v rámci studia nabízeny. V další části jsou popsány a rozebrány cíle a výsledky dotazníkového šetření, kterého se zúčastnili všichni stávající účastníci těchto kurzů v akademickém roce 2020/2021. Autorky se věnují také aktuální problematice online výuky seniorů, stejně jako i motivaci seniorů ke studiu. $V$ diskusi jsou pak porovnány výsledky dotazníkového šetření s poznatky uváděnými v odborné literatuře.
\end{abstract}

Klíčová slova: Univerzita třetího věku, celoživotní vzdělávání, kurzy angličtiny pro seniory, online výuka, motivace, online dotazník

\begin{abstract}
This paper deals with the study of senior citizens at the University of the Third Age (U3V) as part of the University of West Bohemia in Pilsen. While the issue of lifelong learning in the Czech Republic has become increasingly important in the last decades, among other things due to the demographic trends, it has not been sufficiently paid attention to in the specialized literature. The authors of this paper first present the current state of the study at U3V in Pilsen in general terms and then they focus on English courses offered to senior participants. The next part describes and analyzes the aims and results of the online questionnaire, which was filled in by all senior attendees of these courses in the academic year 2020/2021. The following section of the paper tackles the problems connected with teaching English to seniors online and also looks at the motivation of seniors to study. The discussion part aims to compare the questionnaire outcomes with some findings found in the literature.
\end{abstract}

Key words: University of the Third Age, lifelong learning, English courses for seniors, online teaching, motivation, online questionnaire

\section{Univerzita třetího věku (U3V) na Západočeské univerzitě v Plzni - historie a současnost}

Univerzita třetího věku byla založena při Západočeské univerzitě v roce 1992 a během prvních dvou akademických roků (1992/1993 a 1994/1995) zde studovalo v rámci celoživotního vzdělávání 85 účastníků. Od roku 1995 bylo posluchačům, tj. seniorům a rovněž osobám ve třetím stupni invalidního důchodu nabízeno monotematické studium pedagogiky, psychologie a literatury a od akademického roku 1996/1997 se Univerzita třetího věku stala celouniverzitní institucí. U3V ZČU v Plzni je od roku 1996 členem Asociace univerzit třetího věku sdružující instituce, 
které nabízejí a provozují vzdělávací aktivity na úrovni vysokoškolského vzdělávání určené občanům ČR v důchodovém věku.

Působení U3V se postupně od roku 2005 do současnosti rozšírilo do 15 měst Plzeňského a Karlovarského kraje. Rovněž počty přijatých posluchačů postupně narůstaly. V akademickém roce 2019/2020 se ke studiu přihlásilo 2430 posluchačů, v letošním akademickém roce 2020/2021 však došlo k poklesu zapsaných posluchačů na 1953. Snížený počet zájemců o studium mohl být ovlivněn jarní vlnou pandemie a všeobecnou nejistotou, jak se bude epidemiologická situace nadále vyvíjet.

Studium na U3V je od roku 1996 tříleté a studenti mohou ve studiu pokračovat i nadále bez omezení. Zájemcům o studium je po absolvování zápisu vystaven výkaz o studiu a posluchači jsou vybaveni veškerými potřebnými informacemi ohledně pravidel studia. Prezenční studium je organizováno v blocích 90 minutových přednášek nebo seminářủ, přičemž přednášky probíhají zpravidla jednou za dva týdny, celkově osmkrát během semestru, a jazykové semináře se konají každý týden po celý semestr, tedy celkově třináctkrát během semestru. $\mathrm{V}$ závislosti na charakteru oboru studia jsou do výuky zařazovány také praktické činnosti, laboratorní činnosti, cvičení a exkurze. Úspěšné absolvování předmětu je podmíněno vypracováním semestrální práce či testu na požadované úrovni a docházkou v semestru v rozsahu minimálně $60 \%$. Podmínkou úspěšného studia na U3V je účast ve výuce $v$ rozsahu alespoň šesti semestrů a zároveň je třeba, aby posluchač absolvoval alespoň čtyři semestry $\mathrm{v}$ rámci jednoho studijního oboru a alespoň dva semestry v rámci jednoho studijního předmětu. Úspěšní absolventi jsou po skončení př́slušného školního roku zváni k absolutoriu.

\section{Výuka angličtiny na U3V ZČU v Plzni}

Zájemcům o studium anglického jazyka jsou v rámci studia na U3V nabízeny kurzy od akademického roku 2013/2014, v současné době na úrovni A2/B1 a B1/B2 dle Společného evropského referenčního rámce pro jazyky (SERR) a od akademického roku 2020/2021 nově také kurz pro úplné začátečníky (A0 dle SERR). V kurzu je věnována pozornost zvládnutí jazyka studentem z hlediska všech jazykových dovedností, tedy poslechu, čtení, schopnosti konverzace a v omezené míře rovněž kvalitě písemného projevu. Ve výuce jsou využívány učebnice English File Beginner, English File Pre-intermediate a English File Intermediate (Oxford University Press). V akademickém roce 2020/2021 navštěvovalo kurz pro začátečníky 12 posluchačů, kurz pro mírně pokročilé studenty 13 posluchačů a kurz pro středně pokročilé 10 posluchačů. 


\section{Dotazníkové šetření}

Vzhledem k dynamickým změnám, které $\mathrm{v}$ současné době $\mathrm{v}$ oblasti vzdělávání všeobecně probíhají a které se citelně dotkly i jazykové výuky na U3V, se vyučující anglického jazyka rozhodli podrobit stávající frekventanty těchto kurzů dotazníkovému šetření. Cílem tohoto šetření bylo získat podrobnější informace ohledně současného profilu zájemců o studium na U3V, nabýt představu o motivaci seniorů ke studiu obecně, včetně motivace ke studiu anglického jazyka, zjistit úroveň spokojenosti účastníků a rovněž získat vhled do problémů, které této věkové kategorii přináší online výuka.

Po ukončení výuky na konci letního semestru akademického roku 2020/2021 tak obdrželi všichni posluchači kurzů anglického jazyka na U3V ZČU v Plzni odkaz k vyplnění online dotazníku na platformě Google Forms. Vzhledem ke skutečnosti, že dotazník vyplňovali i studenti kurzu pro začátečníky, byly všechny položky v dotazníku naformulovány paralelně v angličtině i češtině. Do dotazníkového šetření se zapojilo 35 studentů (100\%).

Cílovou skupinou tohoto výzkumu byli posluchači tří různých úrovní kurzů angličtiny na U3V ZČU v Plzni v celkovém počtu 35 respondentů. Skupina začátečníků (A0) zahrnovala 12 respondentů (34\%), skupina mírně pokročilých studentů (A2/B1) zahrnovala 13 posluchačů (37 \%) a skupina středně pokročilých (B1/B2) obsahovala 10 studentů $(29 \%)$.

V první části dotazníku byla zjišt’ována obecná charakteristika sledované skupiny respondentů, jejich věk, pohlaví, vzdělání, délka studia na U3V a délka studia anglického jazyka na U3V, doba, po kterou jsou jednotliví posluchači v důchodu a skutečnost, zda ještě někteří stále chodí do práce.

Další část dotazníku postihuje motivaci studentů, tedy důvod, proč se rozhodli pro studium na U3V, kde se o možnosti tohoto studia dozvěděli, a zdali v rámci U3V navštěvují pouze kurzy angličtiny, nebo se věnují i studiu dalších oborů a kterých. Tento oddíl dotazníkového šetření také poskytl odpovědi na otázky, co se respondentům na výuce angličtiny nejvíce líbí, jak často a s kým se nejčastěji učí, jak často vypracovávají domácí úkoly, co při studiu nejvíce používají a jak využívají znalosti angličtiny ve svém životě.

Poslední oddíl dotazníku se týká vynuceného přechodu na online výuku. Cílené otázky zjištují, zda se posluchačům online výuka líbí, nebo nikoliv, a vyžadují konkrétní zdůvodnění pozitivní či negativní odpovědi. Posluchači zde rovněž reagovali na dotaz, co je pro ně při online výuce náročnější, nebo naopak snazší ve srovnání s tradiční prezenční formou výuky. 


\section{Výsledky dotazníkového šetření}

Na základě odpovědí respondentů a rozboru výsledných grafů byly zjištěny skutečnosti, které uvádíme v následující části. $\mathrm{Z}$ důvodu úspory místa $\mathrm{v}$ tomto oddíle shrnujeme získaná data ohledně zkoumaného vzorku studentů bez přiložených grafü.

\section{Charakteristika zkoumaného vzorku studentů}

Poměr pohlaví dané skupiny činil $77 \%$ žen a $23 \%$ mužů. Věk účastníků výzkumu se pohyboval v tomto rozmezí: ve věku 51-60 let byli 2 respondenti ( $6 \%$ ), ve věku 61-70 let bylo 20 respondentů ( $57 \%$ ) a ve věku nad 70 let bylo 13 respondentů (37\%).

V dané skupině nebyl žádný posluchač se základním vzděláním, 18 respondentů (51\%) uvedlo jako nejvyšší dosažené vzdělání středoškolské a 17 respondentů (49\%) uvedlo vzdělání vysokoškolské. Celková doba studia jednotlivých posluchačů na U3V byla zastoupena tímto poměrem: 7 posluchačů (20\%) studuje na U3V po dobu 1-2 semestrů, 11 posluchačů (31\%) zde studuje po dobu 3-4 semestrů, 8 posluchačů ( $23 \%$ ) navštěvuje kurzy U3V po dobu 5-6 semestrů a skupina posluchačů navštěvujících výuku na U3V déle než 6 semestrů je zastoupena 8 studenty $(23 \%)$. U dané skupiny byla rovněž zjištována délka studia angličtiny na U3V ZČU v Plzni. Z celkového počtu 35 posluchačů zde anglický jazyk studuje 18 posluchačů (51 \%) po dobu 1-2 semestrů, 4 posluchači (11 \%) anglický jazyk studují po dobu 3-4 semestrů, 6 posluchačů (17\%) angličtinu studuje po dobu 5-6 semestrů a 7 posluchačů $(20 \%)$ se zde věnuje studiu angličtiny déle než 6 semestrů.

Většina respondentů ( 86 \%) uvedla, že již nechodí do práce, naopak 5 respondentů (14\%) uvádí, že stále pracují. U respondentů bylo dále zjištováno, jak dlouho jsou již v důchodu, přičemž 14 (40 \%) z nich uvedlo, že jsou v důchodu 1-3 roky, následuje skupina čítající 9 respondentů ( $26 \%$ ), kteří jsou v důchodu více než 5 let, dále 7 respondentů ( $20 \%$ ) uvedlo, že jsou v důchodu více než 10 let, a pouze 5 posluchačủ (14 \%) uvádí délku důchodu v rozpětí 3-5 let.

\section{Motivace posluchačů pro studium na U3V a pro studium angličtiny}

První uvedený graf zobrazuje vyhodnocení motivace studentů ke studiu na U3V obecně a druhý graf představuje kurzy, jež jsou mezi seniorskou skupinou studentů nejoblíbenější. Podle zjištění dotazníkového šetření $46 \%$ frekventantů kurzů anglického jazyka zároveň navštěvuje i další kurzy na U3V. 
Why did you decide to become a U3V student?/Proč jste se rozhodl(a) stát se studentem/studentkou U3V?

35 odpovèdi

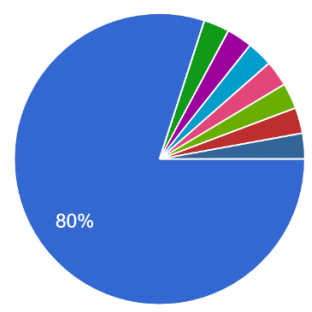

to learn something new/abych se nau...

to meet new people/abych poznal(a) n..

to make friends/abych si našel/našla $n$..

něco se nového naučila i seznámila s...

Byla jsem přihlášena dcerou, dostala j..

A abych nezapomnela anglictinu

Chtěl bych se naučit mluvit anglickým...

Cestovat

$\Delta 1 / 2 \nabla$

Graf 1: Motivace studentů ke studiu na U3V

\section{Legenda ke grafu v češtině:}

Abych se naučil(a) něco nového; abych poznal(a) nové lidi; abych si našel/našla nové prátele; něco se nového naučila i seznámila s novými lidmi; byla jsem přihlášena dcerou, dostala jsem studium jako dárek; abych nezapomněla angličtinu; chtěl bych se naučit mluvit anglickým jazykem; cestovat.

\section{Komentář:}

Pro 30 posluchačů ( $82 \%$ ) byla nejsilnějším motivačním faktorem touha naučit se něco nového. Další spektrum důvodů je víceméně vyrovnané.

Posluchači se přitom o možnosti studia na U3V nejčastěji dozvěděli od svých přátel a kamarádů (43\%), na internetu (37\%), nebo prŕmo na univerzitě (14\%).

Which other courses do you attend at U3V?/Které dalši kurzy navštěvujete na U3V?

16 odpovědí

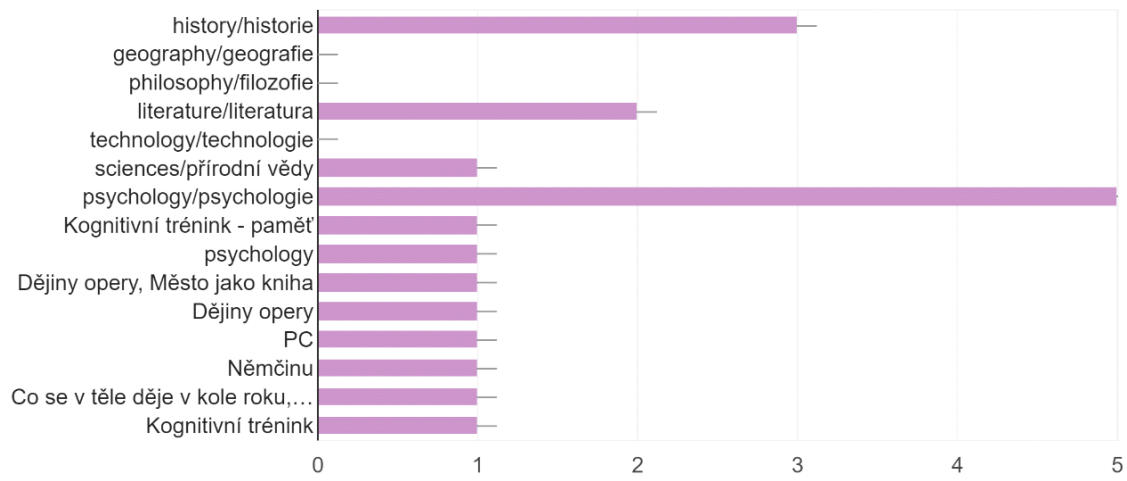

Graf 2: Dalši kurzy, kterých se studenti angličtiny na U3V nejčastěji účastní 


\section{Komentář:}

Z grafu je patrné, že se studenti nejčastěji zároveň věnují studiu psychologie (31\%), historie (19\%) a literatury (13\%).

Na základě odpovědí seniorů na otázku týkající se jejich motivace ke studiu anglického jazyka lze konstatovat, že se jejich motivace ř́́dí specifickými zájmy a potřebami. Nabytých znalostí angličtiny posluchači nejčastěji využívají při cestování (74\%), dále pro trénování mozku a paměti (63\%), při práci na PC (51\%), při četbě $(37 \%)$, při poslechu hudby (29\%) a 10 posluchačů $(29 \%)$ rovněž uvedlo, že se angličtinu učí pro radost.

Motivaci posluchačů nepochybně posiluje také způsob, kterým nabývají znalostí a dovedností a který nejlépe odpovídá jejich naturelu a studijním návykům. Dle dotazníkového šetření prakticky všichni posluchači U3V používají při studiu angličtiny učebnici (97\%), 32 z nich (91\%) používá souborné poznámky z výuky daného týdne, které studenti obdrží krátce po proběhnutí semináře, $83 \%$ posluchačů využívá při studiu internet, 60 \% z nich používá slovník a $40 \%$ frekventantů procvičuje angličtinu za použití různých internetových aplikací. Studenti U3V se nejčastěji učí sami $(77 \%)$, př́ípadně s vnoučaty (23 \%) nebo s kamarády (9\%).
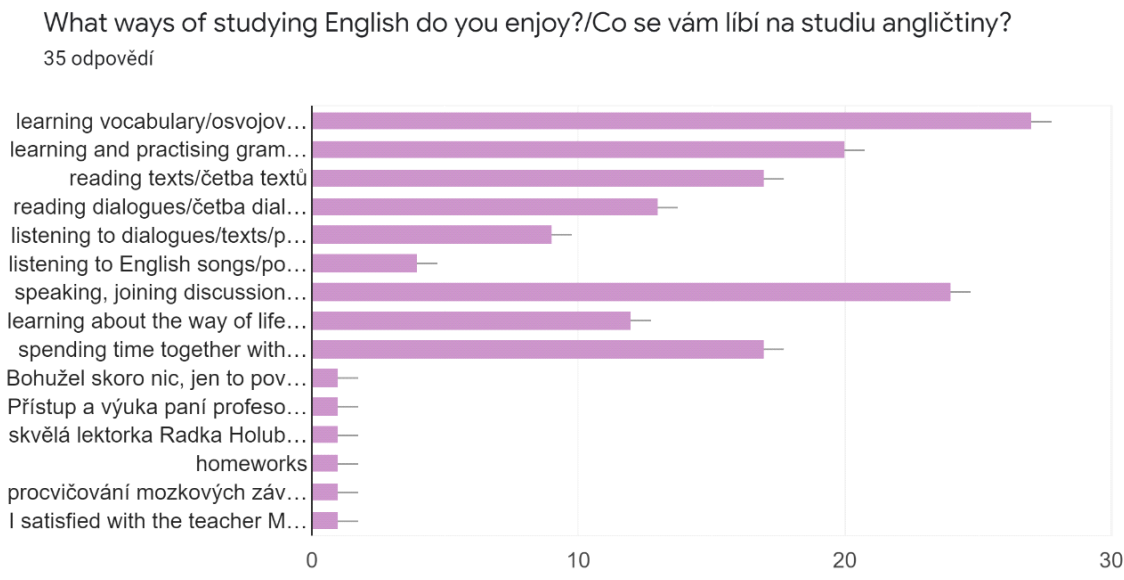

Graf 3: Oblíbené způsoby získávání jazykových znalostí a dovedností

\section{Legenda ke grafu v češtině:}

Osvojování slovní zásoby; osvojování a procvičování gramatiky; četba textů; četba dialogů; poslech dialogů/textů; poslech písniček v angličtině; zapojování se do diskusí; seznámit se se způsobem života v anglicky mluvících zemích; trávení času 
v kolektivu ostatních studentů; bohužel skoro nic, jen to považuji za nutnost; př́stup a výuka paní profesorky; skvělá lektorka; domácí úkoly; procvičování mozkových závitů a návrat do studentských let; jsem spokojen s vyučující.

\section{Komentář:}

Nejoblíbenější činností při studiu angličtiny bylo osvojování slovní zásoby (77 \%), následuje mluvení a zapojování se do diskusí (69\%), osvojování a procvičování gramatiky (57\%), četba textů ( $49 \%$ ) a dialogů (26\%), seznámení se se způsobem života v anglicky mluvících zemích (34\%) a poslech textů a dialogů (26\%). $49 \%$ posluchačů rovněž oceňuje možnost trávit čas v kolektivu ostatních studentů.

What is difficult for you when studying English?/Co je pro vás při studiu angličtiny obtižné?

35 odpovědí

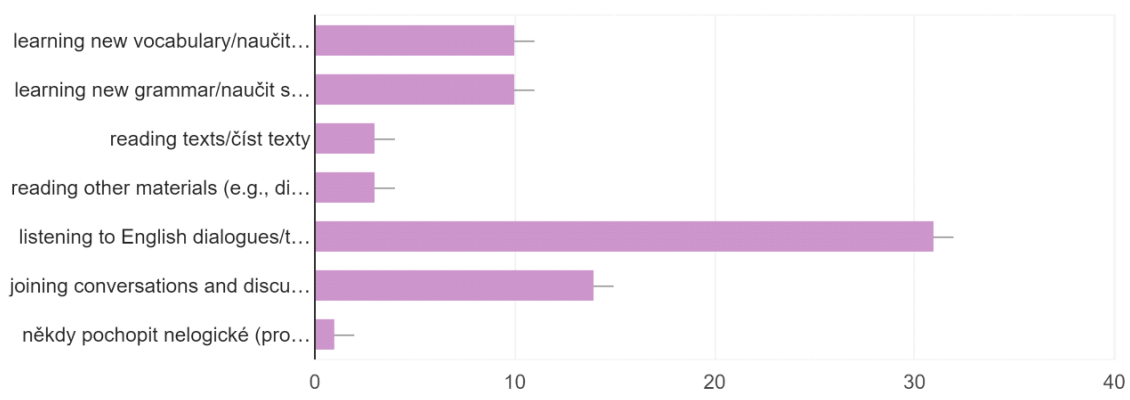

Graf 4: Nejobtižnějši dovednosti při studiu angličtiny

\section{Legenda ke grafu v češtině:}

Naučit se novou slovní zásobu; naučit se novou gramatiku; číst texty; čtení jiných materiálů (např:: dialogů, gramatických pravidel, manuálů); poslouchat dialogy a texty v angličtině; zapojit se do konverzací a diskusí; někdy pochopit nelogické gramatické i fonetické jevy.

\section{Komentář:}

Pro studenty je jednoznačně nejobtížnější dovedností zvládnutí poslechu (89 \%) a zapojování se do konverzací a diskusí (40\%).

Posluchači angličtiny na U3V rovněž reagovali na dotaz, jak často se učí angličtinu, přičemž $49 \%$ z nich kromě účasti v kurzu studuje samostatně nebo s kamará- 
dem/kamarádkou jednou až dvakrát týdně a 29 \% z nich studuje samostatně nebo s kamarádem/kamarádkou častěji než dvakrát týdně.

\section{How often do you do your homework?/Jak často vypracujete domáci úkol z angličtiny?} 35 odpovědí
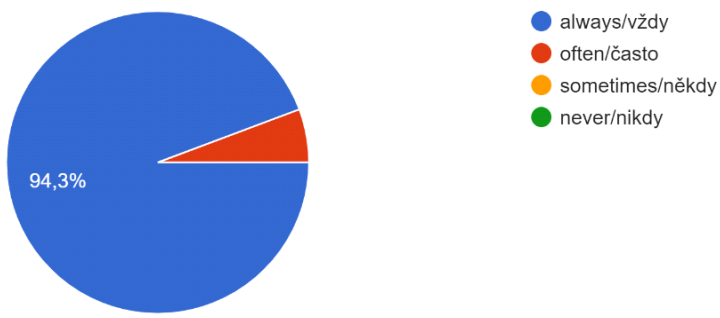

Graf 5: Četnost vypracovávání domácích úkolů

\section{Komentár̆:}

33 posluchačů ( $94 \%$ ) vypracuje domácí úkol každý týden. Pouze 2 posluchači (6\%) vypracují úkol často.

\section{Online výuka anglického jazyka na U3V ZČU v Plzni}

Přechod na distanční výuku byl v důsledku zhoršení pandemické situace velice rychlý, bez adekvátní předchozí přípravy, a byl tudíž obtížný jak pro posluchače kurzů U3V, tak i pro vyučující samotné.

U posluchačů U3V to byla zpočátku hlavně obava z nezvládnutí práce na počítači či jiném moderním technickém zařízení potřebném $\mathrm{k}$ účasti na distanční výuce. Některým posluchačům odpovídající vybavení chybělo a i to bylo důvodem, proč se poněkud zdráhali online výuky účastnit. Na druhou stranu to však byla pro seniory př́ležitost, jak se postavit čelem k výzvě, kterou pro starší generaci moderní komunikační technologie představují, nabýt nových dovedností a také využít výhod z toho plynoucích. K těmto výhodám lze počítat možnost postupně překonat digitální bariéru, získat autonomii ve využívání moderních forem komunikace, a tím napomoci odstranit vnitřní pocit izolace a zaostávání za požadavky současného světa. (Ordanez et al., 2011) Co se týká technických dovedností, může být $\mathrm{v}$ tomto směru také př́nosem postupné zmenšování mezery mezi seniory a tzv. „počítačovou generací“ mladších lidí.

Zavedení online výuky v kurzech U3V nebylo snadné ani pro učitele. Ti se přirozeně obávali nutných změn, které plný přechod na online výuku přináší. Zároveň si nemohli být jisti, zda tento způsob výuky bude natolik efektivní, aby zajistil dosa- 
žení stanovených učebních cílů a stejnou kvalitu učebních výstupů jako výuka prezenční. Při výuce online se totiž role učitele do jisté míry mění. Průběh učebního procesu poskytuje více prostoru pro samostatnější a aktivnější př́stup ze strany studenta, počítá s jeho iniciativou, kreativitou. Student si může lépe řídit tempo, kterým při studiu postupuje, zároveň ale přebírá větší zodpovědnost, pokud jde o výsledky učení. Při online výuce učitel poskytuje studentům podporu a je ve větší míře zprostředkovatelem učebního procesu ve srovnání s výukou kontaktní. Výuka online tak vyžaduje od učitele nové kompetence, protože se nejedná jen o náhražku tradičního způsobu výuky ve tř́dě, ale může jít o modifikaci či dokonce předefinování vyučovacího procesu (Ammenwerth, 2017).

Překotný přechod na online výuku kladl zvýšené nároky také na počítačovou gramotnost učitelů. Ti byli téměř ze dne na den motivováni $\mathrm{k}$ tomu, aby investovali svůj čas a úsilí nejen do svých schopností a dovedností pedagogických, ale zejména do těch, které souvisejí $\mathrm{s}$ technickým zabezpečením online výuky. $\mathrm{V}$ tomto směru byli nápomocni zkušenější kolegové a mentoři, kteří na samém počátku poskytli cenné rady. Učitelům se dostalo také institucionální podpory ve formě celé řady školení a kurzů na podporu a zajištění zdárného průběhu online výuky. Oddělení koncepce celoživotního a distančního vzdělávání ZČU spustilo portál jako metodickou a technickou podporu zaměstnanců ZČU pro využití technologií při výuce. Na tomto portále učitelé najdou užitečné náměty a návody jak online výuku vést i zpestřit, jak testovat online a další př́nosné informace.

Výuka probíhala po celý akademický rok na platformě Google Meet a posluchači měli vždy možnost připojit se do výuky s časovým předstihem, popovídat si se spolužáky a př́padně vyřešit technické problémy za podpory pracovnic z kanceláře U3V. Edukace účastníků poté probíhala bez problémů včetně možnosti pokládání dotazů do chatu. Pomocí kamer a mikrofonu měli všichni posluchači možnost aktivně komunikovat a procvičovat učivo. Účast posluchačů $v$ online výuce anglického jazyka byla srovnatelná, nebo vyšší ve srovnání s předešlými roky, kdy byla výuka realizována tradičně prezenční formou. V akademickém roce 2020/2021 výuka probíhala synchronně na rozdíl od letního semestru předchozího akademického roku, kdy byla výuka realizována asynchronní formou.

Po skončení výuky obdrželi všichni posluchači soubor, který obsahoval podrobné poznámky z výuky daného týdne, aby posloužily nejen jako opora pro studenty, kteří se nemohli v daném týdnu výuky zúčastnit, ale i jako přehledné zopakování pro ty, kteří byli ve výuce př́tomni.

Následující graf znázorňuje podíl kladných a záporných odpovědí na otázku, zda se posluchačům online výuka líbí. 
Do you enjoy studying online?/Libi se vám online studium?

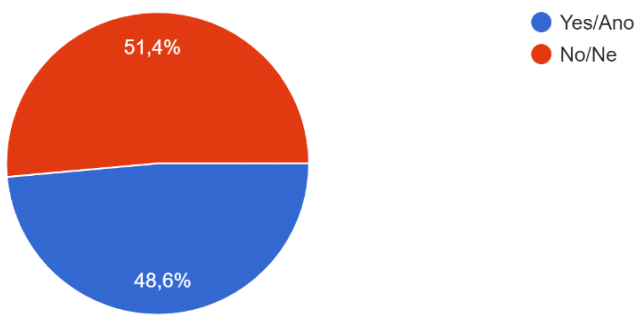

Graf 6: Spokojenost s výukou online

\section{Komentár̆:}

Z grafu je patrné, že rozdíl mezi kladnou a zápornou odpovědí na tuto otázku je zanedbatelný.

Studenti následně individuálně reagovali na dotaz, proč se jim online výuka líbí nebo nelíbí. Z reakcí studentů jednoznačně vyplynulo, že studentům nejvíce chyběla bezprostřednost kontaktu ve třídě, a to jak s vyučujícím tak s ostatními studenty.

Na závěr posluchači odpovídali na dotaz, zda je online studium snazší, či náročnější ve srovnání s prezenční formou studia. 11 posluchačů (31\%) na tento dotaz odpovědělo, že neshledávají rozdíl v náročnosti mezi online a prezenční formou studia.

Podrobnější zdůvodnění toho, co studenti považují za náročnější, nebo naopak méně náročné při studiu online, ukazují grafy níže. 
What is more difficult for you when studying online?/Co je pro Vás při online studiu náročnějši? 24 odpovědí

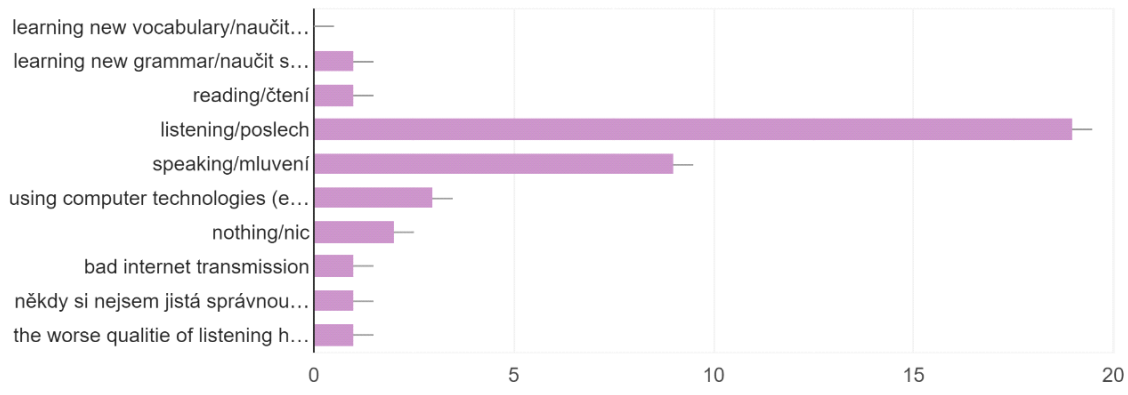

Graf 7: Větší náročnost při studiu anglického jazyka online

\section{Legenda ke grafu v češtině:}

Naučit se novou slovní zásobu, naučit se novou gramatiku; čtení; poslech; mluvení; používání počítačových technologií (napřs: Google Meet); nic; špatné internetové spojení; někdy si nejsem jistá správnou výslovností; horší kvalita poslechu.

\section{Komentár̆:}

Při studiu anglického jazyka online je pro studenty nejnáročnější poslech (79 \% odpovědí), následuje mluvený projev (38 \% odpovědí).

What is easier for you when studying online?/Co je pro Vás při online studiu snazší?

24 odpovědí

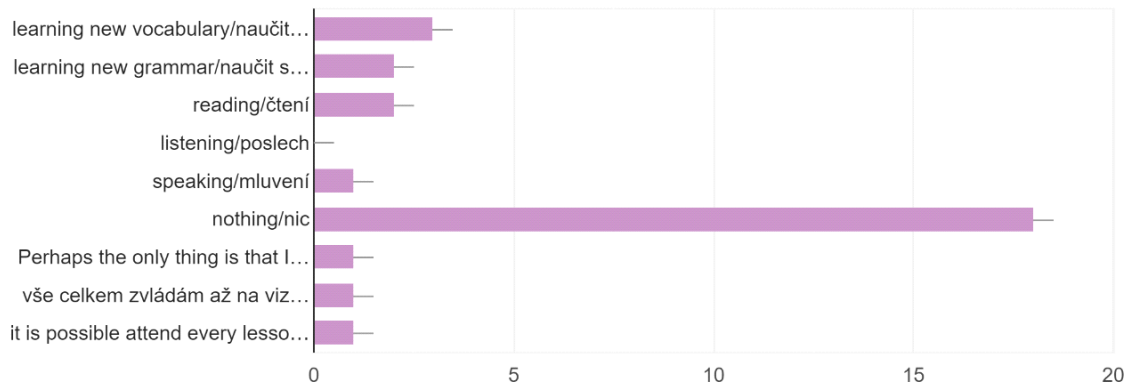

Graf 8: Menší náročnost při studiu anglického jazyka online 


\section{Legenda ke grafu v češtině:}

Naučit se novou slovní zásobu, naučit se novou gramatiku; čtení; poslech; mluvení; nic; pravděpodobně jedině to, že nemusím cestovat do školy v případě špatného počasí; vše celkem zvládám až na viz předchozí otázka; je možné zúčastnit se každé hodiny.

\section{Komentář:}

Z grafu jednoznačně vyplývá, že převážná většina frekventantů U3V (75 \%) neshledává při online výuce žádnou jazykovou dovednost, která by byla v této formě snazší.

\section{Diskuse}

V námi zkoumaném vzorku studentů anglického jazyka na U3V výrazně převažovaly ženy, což nepovažujeme za nijak překvapivé. Skutečnost, že se celoživotního vzdělávání účastní ve valné většině ženy, potvrzují i další studie (Nováková a Lorenzová, 2020), a to nejen v ČR. Například na U3V v Británii a Austrálii ženy představují více než dvě třetiny studujících (Russell, 2007).

$\mathrm{Z}$ důvodu delší doby dožití tvoří ženy početně větší skupinu lidí seniorského věku, mohou tedy více trpět sociální izolací než muži. Vědecké studie zaznamenávají výraznou feminizaci jak v v rekreačních, tak i vzdělávacích a kulturních zájmových skupinách lidí seniorského věku. Jednou z možností jak zvýšit kvalitu života v tomto životním období je aktivní naplňování volného času spolu s rozšiřováním sociálních kontaktů, což nepochybně studium na U3V nabízí.

Vysvětlením menší účasti mužů v celoživotním vzdělávání může být i sama feminizace podobných aktivit, která potenciální mužské účastníky odrazuje, nebo skutečnost, že muži a ženy jsou v podstatě různí a v důchodovém věku rádi dělají různé věci (Williamson, 2000). Pokud jde o studium jazyka, některé studie ukazují, že muži projevují zvláště odmítavý přístup vůči „povídacím“ jazykovým kurzům a podobným činnostem. Muži dávají přednost spíše vlastním volnočasovým aktivitám před těmi, které pro ně někdo organizuje a řídí (Russell, 2007).

Sledovaná skupina účastníků kurzů anglického jazyka na U3V v Plzni byla tvořena převážně respondenty ( $57 \%$ ), které lze označit za mladší seniory, tj. ve věku 61 až 70 let. Převahu mladších seniorů (stadium počátečního stáŕí) potvrzuje i další studie (Nováková, Lorenzová, 2020) zkoumající větší vzorek respondentů, než tomu je v našem př́padě. Nikterak to však nevylučuje možnost, že jiné studie mohou potvrdit převažující počet starších seniorů (nad 70 let) studujících na U3V. 
Z našeho šetření dále vyplynulo, že o studium anglického jazyka na U3V mají zájem absolventi středních a vysokých škol, zatímco senioři se základním vzděláním se ke studiu tohoto jazyka v akademickém roce 2020/21 nepřihlásili. Stejný výsledek, tedy nulový zájem seniorů se základním vzděláním o studium na U3V uvádí studie Novákové a Lorenzové (2020) vycházející ze vzorku 150 respondentů.

Pokud jde o motivaci seniorů ke studiu na U3V, je z analýzy odpovědí respondentů zřejmé, že se $\mathrm{v}$ převážné většině ( $82 \%$ ) ke studiu hlásí z důvodu naplnění své vnitřní potřeby získat nové znalosti a dovednosti. Dalším, avšak proporčně méně významným důvodem byla snaha o rozšíření sociálních kontaktů či navázání nových přátelství (3\%). Žádný z respondentů neuvádí jako motiv studia případné zlepšení své sociální a ekonomické situace či prestiže. Zdá se, že pro tuto věkovou kategorii není tento důvod prioritou. Vysvětlením může být fakt, že 86 \% dotázaných uvedlo, že již nejsou ekonomicky činní.

V souvislosti s přístupem $\mathrm{k}$ online výuce na dotaz na její oblibu byly odpovědi respondentů téměř vyrovnané s mírnou převahou záporných reakcí $(51,4 \%)$. Senioři postrádali atmosféru bezprostředního kontaktu s kolegy i vyučujícími. Tato skutečnost je ve shodě s výchozí hypotézou týkající se obavy seniorů ze ztráty sociální interakce a možnosti kooperace, na kterou byli zvyklí v rámci prezenční výuky. V odborných studiích je však poukazováno na to, že počítačová gramotnost a schopnost pohybovat se $\mathrm{v}$ online prostředí přispívají $\mathrm{k}$ rozšiřování interakce lidí, které spojují společné zájmy (Lee et al., 2011). Kromě pozitivního dopadu na kognitivní funkce starších lidí dochází také $\mathrm{k}$ prožívání pozitivních emocí ve vztahu k sociální interakci. (Shapira et al., 2007). Lze doufat, že po větších zkušenostech budou mít senioři online výuku ve větší oblibě a pod vedením učitele budou využívat všech výhod, které je schopna poskytnout.

\section{Závěr}

Dotazník, do něhož se zapojili studující anglického jazyka na U3V v Plzni, poskytuje soubor dat, která osvětlují některé vybrané aspekty studia seniorů na U3V v současné době. Přestože výsledky dotazníkového šetření vycházejí z odpovědí všech frekventantů kurzů anglického jazyka, jde o malý vzorek respondentů, což je jistě limitujícím faktorem. Přesto se domníváme, že zjištěných poznatků lze využít při další práci $\mathrm{v}$ kurzech $\mathrm{s}$ lidmi seniorského věku, nebot' tato práce má nepochybně svoje specifika. Jde především o využití potenciálu, kterým je motivace těchto posluchačů ke studiu na U3V, a rovněž přizpůsobení forem výuky tak, aby byla tato motivace posilována. Online výuka je aktuální výzvou jak pro vyučující, tak i pro seniory. Vytváří další prostor k zamyšlení nad tím, jak koncipovat a zkvalitňovat učební proces tak, aby byla naplněna očekávání posluchačů U3V $\mathrm{k}$ jejich spokojenosti. $\mathrm{V}$ tomto smyslu by bylo zajímavé porovnat efektivitu výstupů prezenční formy výuky s výstupy výuky vedené výlučně online. 


\section{Literatura}

AMmEnWERTH, E. (2017). Envisioning changing role of university teacher in online instructional environments. AISHE-J. 2017,9,3 [online, vid. 10. 6. 2021]. Dostupné z http://ojs.aishe.org/ index.php/aishe-j/article/view/312

LEE, B. \& CHEN, Y\& HEWITT, L. (2011). Any differences in constraints encountered by seniors in their use of computers and the Internet. Computers in human behaviour 2011, 27 [online, vid. 3. 8. 2021]. Dostupné z https://d1wqtxts1xzle7.cloudfront.net/48203758/Age_differences_in_constraints_ encounter20160820-10215-1ww0hkt-with-cover-page-v2.pdf?Expires=16

NovÁkovÁ, D. \& LoREnzová, J. (2021). Motivation of seniors to learn at the Universities of the Third Age. Sociální pedagogika 2020,8,2 [online, vid. 14.5.2021]. Dostupné z https://doi.org/10.7441/ soced.2020.08.02.05

ORDONEZ, T.N. \& YASSUDA, M.S. \&CACHIONI, M. (2011). Elderly online: Effects of a digital inclusion program in cognitive performance. Archives of Gerontology and Geriatrics 2011, 53 [online, vid. 14. 5. 2021]. Dostupné z https://doi:10.1016/j.archer.2010.11.007

RuSSELl, C. (2007) What do older men and women want? Gender differences in the lived experience of aging. Current sociology 2007, 55,4 [online, vid. 10. 6. 2021]. Dostupné z https://doi.org/10.1177/ 0011392107073300

ShAPIRA, N. \& BARAK, A. \& GAL, I. (2007). Promoting older adults' well-being through Internet training and use. Aging Ment Health 2007,11,5 [online, vid. 15. 5. 2021]. Dostupné z https:// www.tandfonline.com/doi/full/10.1080/13607860601086546

ŠERÁK, M. (2015). Vzdělávání seniorů v České republice-současnost a budoucnost. In P. ADAMEC (Ed.), Současná role celoživotního učení v životě seniorů z multidisciplinární perspektivy: sborník př́spěvků ke konferenci konané u př́ležitosti 25. výročí založení Univerzity třetího věku na Masarykově univerzitě dne 16. záŕí 2015 (pp. 91-99). Brno: Masarykova univerzita.

VERmunt, J. D. \& DonChE, D. (2017). A learning patterns perspective on student learning in higher education: state of the art and moving forward. Educational Psychology Review 2017, 29 [online, vid. 3. 6. 2021]. Dostupné z https://link.springer.com/article/10.1007/s10648-017-9414-6

Williamson, A. (2000). Gender issues in older adults' participation in learning: viewpoints and experiences of learners in the University of the Third Age (U3V). Educational Gerontology 2000, 26, 1 [online, vid. 14. 5. 2021]. Dostupné z https://pubmed.ncbi.nlm.nih.gov/17882585/

\section{Autorky}

Mgr. Radmila Holubová, e-mail: holubova@ujp.zcu.cz, Ústav jazykové př́ípravy ZČU v Plzni. Vystudovala obor Anglický jazyk a literatura a Český jazyk a literatura na FF UK v Praze v roce 1992. Od té doby působí jako vysokoškolský pedagog. V současnosti pracuje v Ústavu jazykové př́ípravy ZČU v Plzni, kde je garantem kurzů obecné angličtiny a angličtiny pro pomáhající profese na Fakultě filozofické a Fakultě pedagogické. Mimo jiné se každoročně věnuje výuce kurzů na Mezinárodní letní jazykové škole pořádané Ústavem jazykové přípravy ZČU a administraci mezinárodních jazykových zkoušek TOEIC. V posledních letech působí především na Fakultě zdravotnických studií a na Univerzitě třetího věku.

Mgr. Jitka Ramadanová, PhD., e-mail: ramadano@ujp.zcu.cz, Ústav jazykové př́ípravy ZČU v Plzni. Vystudovala obor anglický jazyk a literatura a ruský jazyk a literatura na FF UK v Praze v roce 1976. Od té doby působí jako vysokoškolský pedagog. V roce 2011 dokončila doktorské studium na FF ZČU v Plzni, obor Teorie a dějiny vědy a techniky. Absolvovala semestrální studijní pobyt na University of Lancaster a řadu pracovních stáží v UK. V současné době pracuje v Ústavu jazykové přípravy ZČU v Plzni, kde je garantem kurzů anglického jazyka Fakulty ekonomické a také garantem jazykové přípravy studentů doktorského studia na Fakultě elektrotechnické a na Fakultě aplikovaných věd ZČU. 